\title{
Protein content in the diet for fattening lambs. \\ 1. Liveweight gain, efficiency of feed utilization and digestibility of nitrogen and amino acids in the small intestine
}

\author{
Teresa Żebrowska, Hanna Żebrowska and J. Pająk
}

The Kielanowski Institute of Animal Physiology and Nutrition, Polish Academy of Sciences. 05-110 Jablonna, Poland

(Received 17 July 1991; accepted 29 November 1991)

\begin{abstract}
Polish Merino male lambs, average initial weight $16 \mathrm{~kg}$, in 3 groups of 10 , were fed to $38-40 \mathrm{~kg}$ ljveweight on diets with $18,7 \mathrm{MJ} / \mathrm{kg} \mathrm{DM}$ gross energy and $17(\mathrm{H}), 14(\mathrm{M})$ and $10 \%(\mathrm{~L})$ crude protein. Six male lambs of about $40 \mathrm{~kg}$ body weight, with simple duodenal and ileal cannulae were fed in a Latin square design on dicts of similar composition but containing $\mathrm{Cr}_{2} \mathrm{O}_{3}$ and pelleted. Average daily gain in groups $\mathrm{H}, \mathrm{M}$, and $\mathrm{L}$ was 188,180 and $159 \mathrm{~g}$; intake per kg gain was : of metabolizable energy $53.7 ; 52.2$ and $50.4 \mathrm{MJ}$, of crude protein 824,660 and $595 \mathrm{~g}$, respectively. Ammonia $\mathrm{N}$ content in duodenal digesta was on diet $\mathrm{L}$ less than on diets $\mathrm{II}$ and $\mathrm{M}(\mathrm{P} \leqslant 0.05)$. Apparent digestibility of total $\mathrm{N}$ in the small intestine was on diets $\mathrm{H}$ and $\mathrm{M} 68.1 \%$, on diel $\mathrm{L} 65.4 \%$, the difference being significant $(P \leqslant 0.05)$. Absorption of essential amino acids was greatest of Met and Lys and least of Thr, regardless of diet. Decreasing the content of crude protein in diets for Polish Merino male lambs to $14 \%$, at $18.7 \mathrm{MJ}$ gross energy per kg DM, did not reduce the amount of amino acids absorbed in the small intestine and improved protein utilization.
\end{abstract}

KEY WORDS: lambs, protein level, amino acid utilization

\section{INTRODUCTION}

The protein level in diets for fattening lambs recommended by different authors varies widely, from 14 to $24 \%$, depening on the type of the animals, fattening intensity and source of dietary nitrogen. Polish feeding standards (1985) recommend the feeding of fattening lambs on diets with 16 to $17 \%$ crude protein in the dry matter. Results of our earlier experiments (Jayaprakash, 1984) and those of other authors (Urbaniak, 1986) indicate the possibility of reducing the protein content in diets for fattening lambs.

The aim of the present work was to compare the liveweight gain, efficiency of feed utilization, amounts of protein and amino acids in duodenal digesta and

(C) Institute of Animal Physiology and Nutrition 
their digestibility in the small intestine in lambs fed on diets with the recommended or reduced protein level.

\section{MATERIAL AND METHODS}

\section{Experiment 1}

Polish Merino male lambs, initial body weight about $16 \mathrm{~kg}$, in 3 groups of 10 , were kept in pens, at 2 in each on a bedding of wood shavings and fed for 4 months on diets of chopped meadow hay, $20 \%$, and a concentrate mixture, $80 \%$ (Table 1). The diets had 3 different crude protein levels: $17(\mathrm{H}), 14(\mathrm{M})$ and $10(\mathrm{~L}) \%$ in dry matter (DM) (Table 2 ). The daily allowance of feed distributed over 2 meals amounted to $4 \%$ of body weight and was adjusted every 2 weeks following weighing of the lambs; the daily feed intake was recorded. The lambs had free access to water. The digestibility of nutrients was estimated by balance trials with 4 lambs of each group during 6 day collection periods.

\section{Experiment 2}

The experiment was with 6 male lambs, average liveweight $40 \mathrm{~kg}$, two each from the 3 groups of experiment 1 after completed fattening. The lambs were fitted with simple cannulae of the duodenum, about 5 to $10 \mathrm{~cm}$ distal to the pylorus, and of the ileum, about $10 \mathrm{~cm}$ before the ileo-caecal junction. They were fed, in a Latin square design, on diets $\mathrm{H}, \mathrm{M}$ and $\mathrm{L}$, similar to those in experiment 1 but pelleted with $0,4 \% \mathrm{Cr}_{2} \mathrm{O}_{3}$ added (Table 2). The daily allowance, distributed over 2 equeal meals, was $3.5 \%$ of body weight. The lambs were kept individually on a bedding of wood shavings and had free access to water. After 14 days on each diet samples of duodenal and ileal digesta, $50 \mathrm{ml}$ each, were taken every

TABLE 1

Composition of rations, $\mathrm{g} / \mathrm{kg}$

\begin{tabular}{lrcc}
\hline & \multicolumn{3}{c}{ R a t i o n } \\
& H & M & L \\
\hline Meadow hay & 200 & 200 & 200 \\
Barley & 406 & 536 & 226 \\
Rapeseed oilmeal & 200 & 70 & - \\
Linseed oilmeal & 20 & 20 & - \\
Dried sugar beet pulp & 100 & 100 & 500 \\
Oats & 50 & 50 & 50 \\
"Mikrofos" - Mineral & & & \\
$\quad$ mixture & 20 & 20 & 20 \\
$\quad \begin{array}{l}\text { Mineral vitamin } \\
\text { mixture „0" }\end{array}$ & 2 & & \\
\hline
\end{tabular}


TABLE 2

Chemical composition of rations, in percent of DM

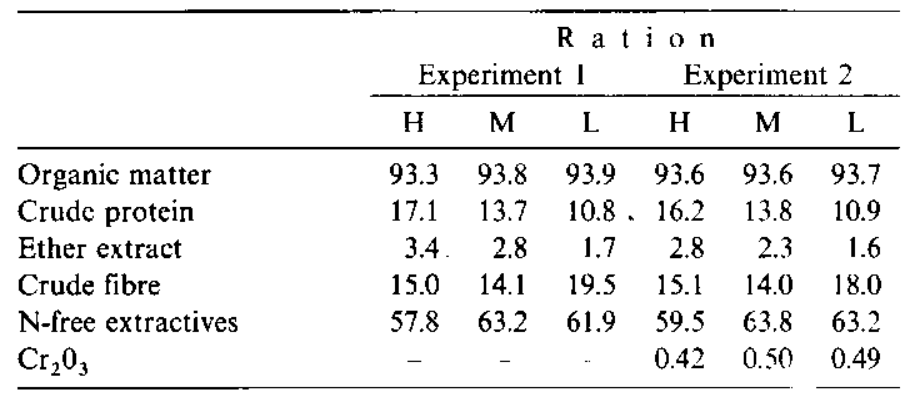

$2 \mathrm{~h}$ during 2 days. The samples were pooled, representing the digesta passing during $48 \mathrm{~h}$. During collection the samples were kept at $-10^{\circ} \mathrm{C}$, thereafter at $-18^{\circ} \mathrm{C}$ until analysed.

Chemical composition of the feed mixtures was estimated by conventional methods. DM of duodenal and ileal digesta was determined in fresh samples. In duodenal digesta, the content of ammonia $\mathbf{N}$ was estimated by the Conway method. In freeze-dried samples of digesta the contents of DM, crude ash and crude protein were estimated by conventional methods. The content of $\mathrm{Cr}_{2} \mathrm{O}_{3}$, by the method of Kimura and Miller (1957), and the amino acid composition of feed and digesta were also determined. All amino acids were estimated with the amino acid analyzer Unichrom (Beckman). Statistical evaluation of the results was by analysis of variance using Student's t-test.

\section{RESULTS}

\section{Experiment 1}

The chemical composition of feeds and rations is given in Tables 1 and 2 . The feed offered was readily eaten; average daily feed intake throughout the experiment was slightly more in group $\mathrm{H}, 1004 \mathrm{~g}$, than in groups $\mathrm{M}, 966 \mathrm{~g}$. and $\mathrm{L}$, $978 \mathrm{~g}$ per lamb. Refusals were, of concentrates 0.8 to $1.6 \%$, of hay 3.3 to $4.4 \%$ of the amounts given in individual groups.

Digestibility of DM, organic matter and $\mathrm{N}$-free extractives of all diets was similar (Table 3). Apparent digestibility of crude protein rose significantly $(P \leqslant 0.01)$ with increasing protein content in the diet. Digestibility of crude fibre was best of diet $L$ and least good of diet $M(P \leqslant 0.01)$. Average daily gain of lambs of group $\mathrm{H}$ and $\mathrm{M}$ (Table 4) was similar 188 and $180 \mathrm{~g}$ and least of group $\mathrm{L}$, but, because of wide individual variation the difference did not reach significance level.

The intake of DM and of gross and metabolizable energy per kg gain on diets 
TABLE 3

Apparent digestibility of nutrients in Experiment 1, in \%

\begin{tabular}{llll}
\hline & \multicolumn{3}{c}{ R a t i o n } \\
\cline { 2 - 4 } & $\mathrm{H}$ & $\mathrm{M}$ & $\mathrm{L}$ \\
\hline Dry matter & 71.8 & 71.3 & 73.2 \\
Organic matter & 74.0 & 73.0 & 75.4 \\
Crude protein & $70.9^{\mathrm{A}}$ & $63.6^{\mathrm{B}}$ & $52.9^{\mathrm{C}}$ \\
Ether extract & $57.5^{\mathrm{A}}$ & $52.2^{\mathrm{A}}$ & -7.0 to 16.4 \\
Crude fibre & $50.1^{\mathrm{A}}$ & $44.2^{\mathrm{B}}$ & $67.3^{\mathrm{C}}$ \\
N-free extractives & 81.6 & $81.8^{-}$ & 83.7 \\
\hline
\end{tabular}

A, B, C $-P \leqslant 0.01$

TABLE 4

Mean feed intake, liveweight gain and feed utilization (animal/day)

in Experiment 1

\begin{tabular}{lccc}
\hline & \multicolumn{3}{c}{ R a t i o n } \\
\cline { 2 - 4 } & H & M & L \\
\hline $\begin{array}{l}\text { Liveweight, kg: } \\
\text { initial } \\
\text { final }\end{array}$ & 15.8 & 15.8 & 16.1 \\
Days of fattening & 37.6 & 36.6 & 34.9 \\
$\begin{array}{l}\text { Feed intake, g: } \\
\text { concentrates }\end{array}$ & 113 & 113 & 116 \\
$\quad$ meadow hay & 800 & 769 & 781 \\
$\begin{array}{l}\text { Daily liveweight gain, g } \\
\text { Feed utilization (kg/kg gain): }\end{array}$ & 204 & 197 & 197 \\
$\quad$ dry matter, kg & 188 & 180 & 159 \\
crude protein, g & & & \\
gross energy, MJ & $4.83^{\mathrm{e}}$ & $4.82^{\mathrm{Aa}}$ & $5.51^{\mathrm{Bb}}$ \\
$\quad$ metabolizable energy, MJ & $824^{\mathrm{A}}$ & $660^{\mathrm{B}}$ & $595^{\mathrm{C}}$ \\
\hline
\end{tabular}

a, b $\quad-P \leqslant 0.05$

A, B, C $-P \leqslant 0.01$

$\mathrm{H}$ and $\mathrm{M}$ was similar and significantly less $(\mathrm{P} \leqslant 0.01)$ than on diet $\mathrm{L}$. The intake of crude protein differed significantly between groups being most in group $\mathrm{H}$ and least in group $\mathbf{L}$.

\section{Experiment 2}

The amounts of crude protein in the DM of the diets were similar to those in experiment 1 . The amounts of organic matter ingested and passing through the 
Organic matter intake and flow through the duodenum and ileum ( $\mathrm{g} / 24 \mathrm{~h})$, in Experiment 2

\begin{tabular}{lrrr}
\hline & \multicolumn{3}{c}{ R a t i o n } \\
\cline { 2 - 4 } & H & M & \multicolumn{1}{c}{$\mathrm{L}$} \\
\hline Intake & 1198 & 1240 & 1181 \\
In duodenal digesta & 752 & 759 & 697 \\
In ileal digesta & 460 & 495 & 462 \\
Apparent digestibility & & & \\
$\quad$ in the stomachs, \% & $37.1^{\circ}$ & $38.7^{a}$ & $41.1^{b}$ \\
Apparent digestibility & & & \\
$\quad$ in the small intestine, \% & 39.2 & 35.3 & 34.4 \\
\hline
\end{tabular}

$a, b-P \leqslant 0.05$

duodenum were similar in all groups (Table 5). The apparent digestibility of organic matter calculated from the difference between the amounts ingested and passing through the duodenum was less in groups $H$ and $M$ than in group $\mathrm{L}(\mathrm{P} \leqslant 0.05$ ). From 39.2 (group $\mathrm{H}$ ) to $34.4 \%$ (group $\mathrm{L}$ ) of the organic matter leaving the abomasum was digested in the small intestine, but the differences were not significant. Nitrogen intake by lambs of group $L$ was less $(P \leqslant 0.05)$ than in groups $\mathrm{H}$ and $\mathbf{M}$ (Table 6 ). Total $\mathbf{N}$ flowing through the duodenum in groups $\mathrm{H}, \mathrm{M}$ and $\mathrm{L}$ was $4.1,5.9$ and $6.9 \mathrm{~g} /$ day more than intake. Daily amount of total $\mathrm{N}$ and non-ammonia $\mathrm{N}$ in duodenal digesta was in group $\mathrm{L}$ significantly less $(P \leqslant 0.05)$ than in groups $H$ and $M$. Daily amount of ammonia $N$ in duodenal

TABLE 6

Mean daily nitrogen intake, nitrogen content in the duodenal digesta and apparent absorption of nitrogen in the small intestine, Experiment 2

\begin{tabular}{|c|c|c|c|}
\hline & \multicolumn{3}{|c|}{$R$ a $t \mathbf{j} \circ \mathrm{n}$} \\
\hline & $\mathbf{H}$ & $\mathbf{M}$ & L \\
\hline $\begin{array}{l}\mathrm{N} \text { intake, } \mathrm{g} / \mathrm{d} \\
\text { In duodenal digesta, } \mathrm{g} / \mathrm{d} \text { : }\end{array}$ & $31.9^{b}$ & $29.2^{b}$ & $21.9^{a}$ \\
\hline total-N & $36.0^{b}$ & $35.1^{b}$ & $28.8^{a}$ \\
\hline $\mathrm{NH}_{3}-\mathrm{N}$ & $1.13^{\mathrm{B}}$ & $0.73^{\mathrm{A}}$ & $0.81^{A}$ \\
\hline non-ammonia $\mathrm{N}$ & $34.9^{b}$ & $34.9^{\circ}$ & $28.0^{\circ}$ \\
\hline Apparent digestibility, \%: & & & \\
\hline in the stomachs & -16.4 & -24.2 & -26.6 \\
\hline in the small intestine & $68.1^{b}$ & $68.1^{b}$ & $65.2^{\circ}$ \\
\hline
\end{tabular}

a, b $-P \leqslant 0.05$

A, B $-P \leqslant 0.01$ 
TABLE 7

Amino acid composition of the rations and of the duodenal digesta of lambs given $\mathrm{H}, \mathrm{M}$ and $\mathrm{L}$ rations $(\mathrm{g} / 16 \mathrm{~g} \mathrm{~N})$

\begin{tabular}{lrrrrrr}
\hline & \multicolumn{3}{c}{ Ration } & \multicolumn{4}{c}{ Duodenal digesta } \\
\cline { 2 - 7 } & $\mathrm{H}$ & $\mathrm{M}$ & $\mathrm{L}$ & $\mathrm{H}$ & $\mathrm{M}$ & $\mathrm{L}$ \\
\hline Asp & 7.4 & 7.2 & 7.6 & 9.0 & 9.0 & 9.2 \\
Thr & 4.1 & 3.8 & 4.2 & 4.7 & 4.5 & 4.6 \\
Ser & 4.5 & 4.3 & 4.6 & 4.5 & 4.3 & 4.4 \\
Glu & 21.7 & 21.3 & 16.6 & 15.9 & 16.7 & 14.2 \\
Pro & 8.1 & 8.3 & 7.1 & 5.2 & 5.4 & 4.6 \\
Gly & 4.9 & 4.6 & 4.7 & 5.3 & 5.1 & 5.0 \\
Ala & 4.6 & 4.5 & 4.7 & 5.4 & 5.5 & 5.5 \\
Val & 5.3 & 5.2 & 5.6 & 5.7 & 5.7 & 5.8 \\
Ile & 3.7 & 3.7 & 3.8 & 4.6 & 4.5 & 4.4 \\
Leu & 7.0 & 6.9 & 6.5 & 7.3 & 7.2 & 7.0 \\
Tyr & 3.0 & 3.0 & 3.7 & 3.5 & 3.4 & 3.5 \\
Phe & 4.6 & 4.6 & 4.4 & 4.6 & 4.6 & 4.5 \\
Lys & 4.6 & 3.7 & 4.9 & 5.8 & 5.8 & 6.5 \\
His & 2.5 & 2.7 & 2.7 & 2.2 & 2.1 & 2.2 \\
Arg & 5.7 & 5.0 & 4.8 & 4.8 & 4.7 & 4.6 \\
Cys & 2.1 & 2.0 & 1.5 & 1.7 & 1.6 & 1.6 \\
Met & 1.9 & 1.7 & 1.6 & 1.9 & 1.7 & 1.9 \\
Trp & 1.2 & 1.1 & 1.0 & 1.3 & 1.2 & 1.2 \\
DAPA & - & - & - & 0.43 & 0.64 & 0.75 \\
\hline
\end{tabular}

digesta was in group $\mathrm{H}$ more $(\mathrm{P} \leqslant 0.05)$ than in other 2 groups. Apparent digestibility of total $\mathrm{N}$ in the small intenstine was in groups $\mathrm{H}$ and $\mathrm{M}$ similar and greater than in group $\mathrm{L}(\mathrm{P} \leqslant 0.05)$.

The amino acid composition of duodenal digesta was similar on all diets (Table 7). The daily amount of most essential amino acids in the duodenal digesta (Table 8) depended on the diet given and was greater $(P \leqslant 0.01)$ in groups $H$ and $M$ than in group $L$. On the other hand, 2.6-diaminopimelic acid (DAPA) in duodenal digesta was more in groups $M$ and $L$ than in group $H$. Apparent digestibility of essential amino acids in the small intestine surpassed that of total $\mathrm{N}$ (Table 9). Apparent digestibility of individual amino acids, except lysine and valine, was greater $(P \leqslant 0.05)$ in groups $H$ and $M$ than in group $L$. Of the essential amino acids, absorption was most of methionine and lysine, regardless of diet. Apparent absorption was least of threonine, $69.8,65.6$ and $65 \%$ on diets $\mathrm{H}$, $\mathbf{M}$ and $\mathrm{L}$, respectively. Of the non-essential amino acids, absorption was least of cystine and glycine and most of arginine. 
TABLE 8

Mean amount of amino acids passing through the duodenum $(\mathrm{g} / 24 \mathrm{~h})$

\begin{tabular}{lccc}
\hline & \multicolumn{3}{c}{ R a t i o n } \\
\cline { 2 - 4 } & H & M & L \\
\hline Asp & $20.4^{a}$ & $19.7^{a}$ & $16.5^{b}$ \\
Thr & $10.6^{a}$ & $9.9^{b}$ & $8.3^{b}$ \\
Ser & $10.1^{a}$ & $9.5^{b}$ & $7.9^{b}$ \\
Glu & $35.8^{A}$ & $36.7^{A}$ & $25.5^{B}$ \\
Pro & $11.7^{A}$ & $11.8^{A}$ & $8.2^{B}$ \\
Gly & $11.8^{a}$ & $11.2^{a}$ & $9.0^{b}$ \\
Ala & $12.2^{a}$ & $12.0^{a}$ & $9.9^{b}$ \\
Val & 12.8 & 12.6 & 10.4 \\
Ile & $10.2^{A}$ & $9.8^{A}$ & $7.8^{B}$ \\
Leu & $16.4^{a}$ & $15.9^{a}$ & $12.5^{b}$ \\
Tyr & $7.8^{a}$ & $7.5^{a}$ & $6.2^{b}$ \\
Phe & $10.3^{a}$ & $10.0^{a}$ & $8.0^{b}$ \\
Lys & 13.1 & 12.7 & 11.7 \\
His & 4.9 & 4.6 & $4.0^{b}$ \\
Arg & $10.7^{a}$ & $10.4^{a}$ & $8.4^{b}$ \\
Cys & $3.8^{a}$ & $3.5^{a}$ & $2.8^{b}$ \\
Met & $4.3^{a}$ & $3.8^{b}$ & $3.3^{b}$ \\
Trp & $3.0^{a}$ & $2.7^{a}$ & $2.2^{b}$ \\
DAPA & 0.97 & 1.40 & 1.35 \\
\hline
\end{tabular}

a, $b-P \leqslant 0,05$

A, B $-P \leqslant 0,01$

TABLE 9

Apparent digestibility of amino acids in the small intestine, $\%$

\begin{tabular}{lccc}
\hline & \multicolumn{3}{c}{ R a t i o n } \\
\cline { 2 - 4 } & H & M & L \\
\hline Asp & 74.5 & 73.6 & 72.7 \\
Thr & 69.8 & 65.6 & 65.0 \\
Ser & 72.3 & 69.5 & 67.0 \\
Glu & 77.4 & 77.1 & 72.5 \\
Pro & 69.2 & 71.2 & 68.3 \\
Gly & 71.2 & 69.6 & 64.4 \\
Ala & 72.1 & 69.2 & 68.7 \\
Val & 76.6 & 72.7 & 73.0 \\
Jle & 80.4 & 78.6 & 75.6 \\
Leu & 79.3 & 78.0 & 76.0 \\
Tyr & 80.8 & 78.7 & 75.8 \\
Phe & 80.6 & 79.0 & 76.2 \\
Lys & 76.3 & 75.6 & 76.9 \\
His & 71.4 & 71.7 & 70.0 \\
Arg & 84.1 & 83.6 & 82.1 \\
Cys & 50.0 & 51.4 & 67.8 \\
Met & 83.7 & 81.6 & 69.7 \\
Trp & 73.0 & 70.4 & 68.2 \\
\hline
\end{tabular}




\section{DISCUSSION}

In both experiments the feed was eaten readily with only a small amount of refusals left. The intake of crude protein by lambs on diet $\mathrm{H}$ was more than intended and more than in experiment 2 because of slightly better ingestion of concentrates and less good of hay by lambs of this group. In experiment 2, to ensure a more uniform intake of hay and concentrates, and to prevent from losses of $\mathrm{Cr}_{2} \mathrm{O}_{3}$, the feed was pelleted. In this experiment, diet $\mathrm{H}$ was eaten slightly less readily than in experiment 1 ; in consequence the difference in $\mathrm{N}$ intake in groups $H$ and $M$ was small. The growth of lambs on diets $H$ and $M$ was similar and better than on diet L. Daily gain was similar to that reported by other authors with Polish Merino lambs (Chomyszyn et al., 1973; Jayaprakash, 1984; Borys et al., 1987; Urbaniak, 1986; Kowalczyk at al., 1986; Zebrowska et al., 1987) and by Australian workers (Wynn and Thwaites, 1981; Soeparno and Davis, 1982). The poor daily gain of lambs on diet $L$ indicated that $11 \%$ crude protein in DM of the diet did not meet the requirement of growing lambs as reported earlier by Urbaniak (1986). No differences in liveweight gain between lambs of groups $H$ and $M$ and a markedly better protein utilization in group $M, 660$ vs $824 \mathrm{~g} / \mathrm{kg}$, suggested excess protein in diet $H$. Intake of DM and metabolizable energy per $\mathrm{kg}$ gain was in group L significantly more than in the remaining groups, approaching that obtained by Jayaprakash (1984) but less than in other experiments with fattening Merino lambs (Chomyszyn et al., 1973; Urbaniak, 1986; Pakulski et al., 1986; Osikowski et al., 1986). Apparent digestibility of protein declined with decreasing amount of protein in the diet, this being a well known phenomenon resulting from increased proportion of metabolic liecal nitrogen. Low digestibility of ether extract of diet $\mathrm{L}$, accompanied by wide individual differences, was due to the small proportion of this constituent in that diet, containing a large proportion of sugar beet pulp.

Results of other authors (ARC, 1980) indicate that apparent digestibility of organic matter in the forestomachs of sheep, ranging from 35 to $70 \%$, depends on the nature of the feeds given; values most frequently found are 50 to $65 \%$. Apparent digestibility of organic matter in the rumen of lambs on diets $\mathrm{H}, \mathrm{M}$ and $\mathbf{L}$ approached the lowest values reported in literature. This could have been due to the physical form of diets. It has been shown that finely ground and pelleted feed leave the rumen faster than those coarsely ground, reducing the digestibility of organic matter in this part of the digestive tract (Beever et al., 1972). Higher apparent digestibility in the rumen of organic matter of diet $L$ than of $H$ and $M$ was a consequence of the higher proportion of sugar beet pulp rich in readily fermentable carbohydrates. Numerous studies comparing the amounts of $\mathrm{N}$ ingested and flowing through the duodenum indicate that the amount of $\mathrm{N}$ in the duodenum can be greater than that ingested, the difference being the greater the less $\mathrm{N}$ the diet contains (ARC, 1980). It is assumed that with $13 \%$ crude 
protein in the diet the amount of $\mathrm{N}$ leaving the abomasum is similar to that ingested. In the present study, daily $\mathrm{N}$ flow through the duodenum on diets $\mathrm{H}$, $M$ and $L$ was 13,20 and $31 \%$ more than $N$ intake, indicating that even with $16 \%$ protein in the diet the $\mathrm{N}$ balance in the forestomachs was positive; this means that secretion of endogenous $\mathrm{N}$ into the rumen exceeded $\mathrm{N}$ absorption from that part of the intestinal tract. The ratio of the amounts of $\mathrm{N}$ and amino acids passing through the duodenum to their intake indicates the proportion of microbial protein or degradation of dietary amino acids. The ratio, being wide at low protein intake becomes narrow as the intake increases (Harrison et al., 1973). The amount of undegraded dietary protein in duodenal digesta was not estimated but the amino acid composition of the digesta and DAPA content suggested a considerable proportion of microbial protein. A comparison of the average amount of individual amino acids in the feed, duodenal digesta and microbial protein (Ørskov, 1982) indicated that the proportion of microbial protein in the digesta was largest on diet L. Judging from the DAPA content the proportion of bacterial protein in total protein of duodenal digesta amounted to from $46 \%$ in group $H$ to $82 \%$ in group $L$ and influenced largely the amino acid composition of duodenal digesta. The amount of protein in the diet affected the flow of amino acids through the duodenum; on diet $\mathrm{L}$ the amount of individual amino acids was lees than on diet $\mathbf{H}$ and $\mathbf{M}$.

In groups $H$ and $M 68 \%$, in group $L 65 \%$ of total $N$ passing through the duodenum were absorbed in the small intestine; this was constistent with the results of other authors (Salter and Smith, 1977; Coelho da Silva et al., 1972) but less than those obtained by Chamberlain and Thomas (1979) with sheep fed on a diet of barley and sugar beet pulp.

The apparent digestibility of amino acids in the small intestine was similar to that reported by other authors (Faitchney and White, 1979; Lindsay et al., 1984) and less on diet $\mathbf{L}$ than $\mathbf{H}$ and $\mathbf{M}$. From among the essential amino acids, absorpion was least of threonine and most of methionine; this was also observed in pigs (Żebrowska, 1984). Apparent absorption of cystine was cosiderably less than of other amino acids. The reason of the low apparent digestibility of threonine and cystine may be their relatively large amounts in the endogenous protein secreted into the lumen of the small intestine (Zebrowska and Kowalczyk, 1991).

The similar amounts of non-ammonia $\mathrm{N}$ and of individual amino acids in the duodenal digesta, and their similar digestibility in the small intestine of lambs on diets $\mathbf{H}$ and $M$ suggest the supply of similar quantities of amino acids for metabolism. On diet $\mathrm{L}$, both the amounts and apparent digestibility of amino acids were less; consequent upon that, liveweight gain was similar in groups $H$ and $M$ and less in group $L$.

In conclusion it can be said that the reduction of crude protein content in diets of Polish Merino male lambs during fattening from $16-17 \%$ to $14 \%$, at the gross 
energy content of $18.7 \mathrm{MJ} / \mathrm{kg} \mathrm{DM}$ did not decrease the amounts of amino acids absorbed from the small intestine or adversely affect liveweight gain while improvig protein utilization.

\section{REFERENCES}

Borys B., Dulcwicz R, Orzechowska W., Osikowski M., 1986. The fattening performance and slaughter value of lambs from two-step industrial crossing of Merino ewes with highly fertile breed rams (Friesian and Olkuska sheep) and meat breed rams. Zesz. probl. Post. Nauk rol. 303, 299-308

Beever D.E., Coelho da Silva J.F.. Prescott J.H.D., Armstrong D.C., 1972. The effect in sheep of physical form and stage of growth on the sites of digestion of a dried grass. 1. Sites of digestion of organic matter, energy and carbohydrate. Br. J. Nutr. 28, 347-356

Chamberlain D.G., Thomas P.C., 1979. Ruminal nitrogen metabolism and the passage of amino acids to the duodenum in sheep receiving diets containing hay and concentrates in various proportions. J. Sci. Food Agric. 30, 677-686

Chomyszyn M., Kużdowicz M., Kowalczyk J., Orzeszko E., Tomerska H., Ziolecki A., 1973. Nutritive value of dehydrated maize meal (whole plant) in feeding lambs. Rocz. Nauk Rol. B-94, 4, $17-23$

Coelho da Silva J.F., Seeley R.C., Thomson D.J., Beever D.F., Armstrong D.C., 1972. The effect in sheep of physical form on the sites of digestion of a dried lucerne diet. 2. Sites of nitrogen digestion. Br, J. Nutr, 28, 43-61

Faichney G.J., White G.A., 1979. Formaldehyde treatment of concentrate diets for sheep. III. Absorption of amino acids from the small intestive. Aust. J. Agric. Res. 30, 1163-1175

Harrison D.G., Beever D.E., Thomson D.J., Osburn D.F., 1973. The influence of diet upon the quantity and types of amino acids entering and leaving the small intestine of sheep. J. Agric. Sci., Camb. 81, 391-401

Jayaprakash, 1984. Influence of various sources of nitrogen in the diet on the digestibility, nitrogen metabolism, growth and carcass composition of Polish Merino lambs. Ph.D. Thesis. Institute of Animal Physilogy and Nutrition. Jabłonna

Kimura F.T., Miller V.L., 1956. Improved determination of chromic oxide in cow feed and feces. J. Agric. Food Chem., 5, 216-221

Kowalczyk J., Otwinowska A., Jaczewska A., Osikowski M., Pakulski T., 1986. A barley-urea preparation replacing protein for fattening lambs. Rocz. Nauk rol. B-102, 4, 39-50

Lindsay J.R., Hogan J.P., Donnelly J.B., 1980. The digestion of protein from forage diets in the small intestine of the sheep. Aust. J. Agric, Res. 31, 589-600

Lu Ch.D., Jorgensen N.A., Barrington G.P., 1983. Quantitative studies of amino acid flow in the digestive tract of shcep fed alfalfa protein concentrates. J.Nutr. 113, 2390-2402

Nutrient Requirements of Farm Animals, 1985, PWRiL, Warszawa

Osikowski M., Borys B., Pecyna J., Skonieczny J., 1986. The fattenig performance and slaughter value of lambs two-step industrial crossing of Merino sheep and Finnish breed and meat breed rams. Zesz. probl. Post. Nauk rol. 303, 287-297

Grskov E.R., 1982. Protein nutrition in ruminants. Academic Press, London, 19-39

Pakulski T., Korman K., Osikowski M., 1986. Preliminary results of investigation on the fattening performance, slaughter value and meat quality of lambs of Polish Merino breed. Kamieniccka sheep and their crosses. Zesz. probl. Post. Nauk rol. 303, 263-271

Pakulski T., Osikowski M., 1986. Fattening performance, slaughter value and meat quanlity of lambs from crossing of the Bulgarian Merino with Polish and German Merino. Zesz. probl. Post. Nauk rol. $303,251-261$

Salter D.N., Smith R.H., 1977. Digestibilities of nitrogen compounds in rumen bacteria and in other components of digesta in the small intestine of the young steer. Br. J. Nutr. 38. 207-216

Soaperno H.J., Davis H.L... 1982. The effect of dietary energy concentration on growth and carcass composition in Daldale wether shecp. Proc. Aust. Soc. Anim. Prod. 14, 503-506 
The Nutrient Requirement of Ruminant Livestock. 1980. Commonwealth Agricultural Bureaux, London

Urbaniak M., 1986. Protein requirement of Merino lambs fattened from 20 to $40 \mathrm{~kg}$ liveweight. Rocz. Akademii Rolniczej, Poznań, Rozpr. Nauk., 161

Wynn P.C., Thwaites C.J., 1981. The relative growth and development of the carcass tissues of Merino and crossbreed rams and wethers. Aust. J. Agric. Res. 32, 947-956

Żebrowska T., 1984. Estimation of amino acids digestibility in feeds for pigs. Post. Nauk rol.31, 21-37

Żebrowska T., Kowalczyk J., 1991. Nitrogen secretion into isolated loops of the small intenstine in conscious sheep. J. Anim. Physiol. a. Anim. Nutr. 65, 133-139

\section{STRESZCZENIE}

Poziom bialka w dawkach dla tuczonych jagniat. 1. Przyrosty, wykorzystanie paszy oraz strawność azotu i aminokwasów w jelicie cienkim

Trzydzieści tryczków merynosa polskiego o średniej początkowei malsie ciała $16 \mathrm{~kg}$ podzielono na 3 grupy po 10 i żywiono do końcowego ciężaru $38-40 \mathrm{~kg}$ dawkami zawicrającymi I (H), 14 (M) i 10 (L) \% bialka ogólnego przy energii brutto $18,7 \mathrm{MJ} / \mathrm{kg}$ suchej masy. Szexi lryczków o masie ciała okolo $40 \mathrm{~kg} z$ przetokami prostymi do dwunastnicy i jelita biodrowego żywiono w ukladzie kwadratu laciniskiego dawkami o takim samym składzie, ale zawierającymi $\mathrm{Cr}_{2} \mathrm{O}_{3}$ i granulowanymi. Średni dzienny przyrost jagniąt grup II, M i L wynosił odpowiednio $188,180 \mathrm{i} 159 \mathrm{~g}$. Zużycie enrgii metabolicznej na $1 \mathrm{~kg}$ przyrostu wynosiło $53,7,52,2 \mathrm{i} 60,4 \mathrm{MJ}$, a białka ogólnego $824,660 \mathrm{i} 595 \mathrm{~g}$ w grupach $\mathrm{H}, \mathrm{M} \mathrm{i} \mathrm{L}$, odpowiednio. Zawartość $\mathrm{N}-\mathrm{NH}_{3}$ w treści dwunastnicy przy żywieniu dawką L była mniejsza $(\mathbf{P} \leqslant 0.05)$ niż $\mathrm{H}$ i M. Strawność pozorna azotu ogólnego w jelicie cienkim wynosiła $68,1 \%$ w grupach H i M i $65,2 \% \mathrm{w}$ grupie $\mathrm{L}(\mathrm{P} \leqslant 0.05)$. Spośród aminokwasów niezbędnych w największym stopniu uległy wchłonięciu Met i Lys i w najmniejszym Thr przy żywieniu wszystkimi dawkami. Wyniki doświadezenia wskazują, żc obniżenic zawartości białka ogólnego w dawkach dla jagniąt tryczków merynosa polskiego do $14 \%$ przy energii brutto $18,7 \mathrm{MJ} / \mathrm{kg}$ suchej masy nie zmniejszyło ilości aminokwasów wchłoniętych w jelicie cienkim oraz przyrostów masy ciała, natomiast poprawiło wykorzystanie bialka. 